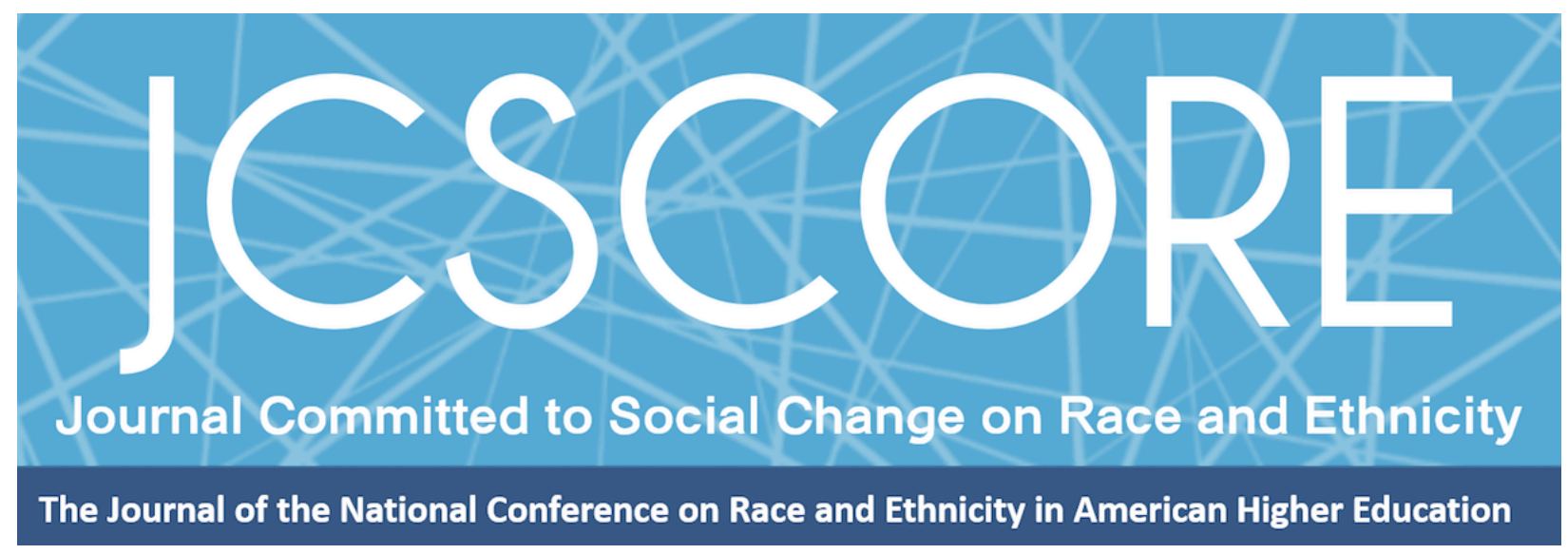

\title{
LETTER FROM THE EDITORS: ADVANCING JCSCORE'S RESEARCH AND PRACTICE
}

Cristóbal Salinas Jr., Editor-in-Chief

Florida Atlantic University

Bruce Busby, Editor-in-Chief

Community College of Rhode Island

Belinda P. Biscoe, Executive Associate Editor

Southwest Center for Human Relations Studies

University of Oklahoma Outreach

Ajia I. Meux, Managing Editor

Southwest Center for Human Relations Studies

University of Oklahoma Outreach

Journal Committed to Social Change on Race and Ethnicity

Volume 5, Issue 1 | 2019

Copyright ( 2019 Board of Regents of The University of Oklahoma on behalf of the Southwest Center for Human Relations Studies.

Permission of the Publisher is required for resale or distribution and for all derivative works, including compilations and translations. Quoting small sections of text is allowed as long as there is appropriate attribution. 


\title{
Letter from the Editors: Advancing JCSCORE's Research and Practice
}

\author{
Cristóbal Salinas Jr., Editor-in-Chief \\ Florida Atlantic University \\ Bruce Busby, Editor-in-Chief \\ Community College of Rhode Island
}

Belinda P. Biscoe, Executive Associate Editor Southwest Center for Human Relations Studies University of Oklahoma Outreach

Ajia I. Meux, Managing Editor Southwest Center for Human Relations Studies University of Oklahoma Outreach

Over the past four-years, the Journal Committed to Social Change on Race and Ethnicity (JCSCORE) has remained committed to serve as the forum for scholars and practitioners to promote an exchange of ideas that can transform lives, enhance learning, and improve human relations in higher education. As JCSCORE continues to make an impact at the national and international level, it has seen tremendous growth for its readers, authors and editorial board.

An exploratory case study for JCSCORE was published in Publications. This case study highlighted the interests, attitudes, and opinions of participants of the National Conference on Race and Ethnicity in American Higher Education (NCORE), and their initial support for the development of what is today JCSCORE (Salinas, 2018). 
Journal Committed to Social Change on Race and Ethnicity | 2019

In recognition for their collaboration and contributions to social justice, the editorial board of JCSCORE received the Outstanding Social Justice Collaboration Award, Commission for Social Justice Educators (CSJE), during the ACPA - College Student Educators International 2017 conference in Columbus, Ohio.

In 2018, the South Center for Human Relations Studies (SWCHRS) at the University of Oklahoma Outreach initiated a formal relationship with OU Libraries to migrate the journal to the Open Journal System \& Public Knowledge Project platform. This new platform institutionalized JCSCORE, increasing access for readers and positioning the journal as a leader in research on how to improve campuses across the country. JCSCORE's publishing platform was announce at NCORE 2019 in Portland, Oregon. To learn more about our new platform visit JCSCORE's website (http://jcscore.org)

Last, in recognition for their hard work in migrating the journal to the Open Journal System \& Public Knowledge Project platform, in February 2019, Cristobal Salinas Jr. was appointed co-editor-in-chief and Ajia I. Meux, Project Development Manager for SWCHRS, was appointed managing editor.

As editors of JCSCORE, we are committed to a rigorous peer-review process and the open dissemination of scholarship. JCSCORE will continue to provide immediate open access to its content on the principle that making research freely available to the public supports a greater global exchange of knowledge. All content in JCSCORE is freely available without charge to the user or their institutions. 
Through each JCSCOREs published issue, we are advancing research and its practical application of the study of race, ethnicity, and sovereignty on social justice in higher education. The spring 2019 issue features manuscripts from the following that provide innovative ways to frame intellectual and critical work:

D-L Stewart offers some thoughts on how to move higher education research on race and ethnicity forward by first looking back on its history and the lessons learned.

Courtney L. Luedke, Dorian L. McCoy, Rachelle Winkle-Wagner, and Jamila LeeJohnson's multi-site case study examines the holistic mentoring practices provided by faculty to Students of Color in STEM fields.

Stephanie J. Waterman highlights a brief history of higher education's role in assimilation, oppression, and removal of Indigenous people, and provides thoughts about the future of new research perspectives on Native American students.

Christina W. Yao and Tiffany Viggiano examine the ways in which a brief of amicus curiae submitted by the American Council on Education and 32 additional higher education associations revealed the commodification of international students and scholars when using interest convergence as an analytical frame for examining the soft power.

We are thankful to all the authors who contribute through their scholarship; to our readers for their commitment to read JCSCORE's published articles, and to all editorial 
board members for their review of manuscripts. Also, thank you to all those that have volunteered their time to help advance the journal. Thank you to the OU Libraries staff David Corbly, Jen Waller, Nick Cousino, and Sara Huber - for your guidance and direction in migrating JCSCORE to the Open Journal System \& Public Knowledge Project platform. Thanks to Florida Atlantic University doctoral students Ethan C. Swingle and Katherine Coulson, for volunteering their time to help the editors. Lastly, a thousand thanks to all the Southwest Center for Human Relations Studies Staff members for their continued support - Belinda Biscoe, Ajia Meux, Anthony Natale, Julie Tate, Courtney Floyd, Jane N. Irungu, Justin Lincks, Kathie Nicoletti, Corey Davidson, Josephine Bozek-Stocks, Kathy Cozad, and Debbie O'Dell.

As always, we invite you to engage in critical conversations, to build new collaborations, and to look for new ideas to take back to your campuses and your communities during your time at NCORE 2019 in Portland, Oregon. If you see someone standing by themselves, talk to them. Start the conversation. At the sessions, ask questions of the presenters and facilitators. Take notes. Share your lived experiences, thoughts, and ideas with the NCORE community. Lastly, we invite you to follow us and join the conversation via Twitter @JCSCORE

\section{Reference}

Salinas, C. (2018). A case study for a new peer-review Journal on Race and Ethnicity in American Higher Education. Publications, 6(26), 1-12. 